\title{
Discounted Preferred Stock under the New Section 305 Treasury Regulations: On Confusing Debt and Equity
}

Under the leadership of Chairman Wilbur Mills and the House Ways and Means Committee, Congress, on December 10, 1969, enacted massive and controversial tax legislation. ${ }^{1}$ Portions of the Tax Reform Act of 1969 manifested a clear anticonglomerate policy; key proponents of tax reform believed that tax advantages encouraged corporate consolidations which otherwise lacked economic justification. ${ }^{2}$ Consequently many of these advantages were eliminated.

With the lion's share of publicity focused on reform of the tax treatment of debt-financed acquisitions, little attention was paid to the Act's revision of stock dividend treatment under $\S 305$ of the Internal Revenue Code. ${ }^{3}$ Section 305 extended to the Treasury broad authority to establish by regulation constructive stock dividend taxation of preferred stock carrying a redemption premium, generically referred to as "discounted preferred." 4 Discounted preferred stock bears functional similarity to original issue discount debt-debt which is issued at a price below maturity value and generally pays a stated amount of interest which is less than prevailing rates. As part of its anticonglomerate package, Congress revised the taxation of such indebtedness, requiring debtholders to realize as income a pro rata amount of the discount each year. Section 1232, the relevant provision of the Code, had previously allowed original issue discount bond-

1. Act of Dec. 30, 1969, Pub. L. No. 91-172, 83 Stat. 610 [hereinafter cited as the Tax Reform Act of 1969 or as the Act].

2. H.R. REP. No. 413, 91st Cong., 1st Sess., pt. 1, at 101.03 (1969) [hereinafter cited as H.R. REP.]; S. REP. No. 552, 91st Cong., 1st Sess. 146.48 (1969) [hereinafter cited as S. REP.].

3. See, e.g., Hearings on the Subject of Tax Reform Before the House Comm, on Ways and Means, 91st Cong., lst Sess., pt. 14, at 5512 (1969) (statement of Edwin S. Cohen, Ass't Sec. of the Treasury for Tax Policy). See generally Bittker, Proposed Legislative Restrictions on Acquisitions of Stock by Conglomerate Corporations, $30 \mathrm{~J}$. TAx. 354 (1969); Thrower, Conglomerates-Some Tax Problems, 25 Bus. LAw. 641 (1970).

4. Treas. Reg. \& 1.305-5(b)(1) (1973) gives a precise description: This is stock "which may be redeemed [by the issuing corporation] after a specified period of time at a price higher than the issue price...." Note that such preferred stock, according to this definition, does not necessarily bear a mandatory redemption provision.

Prior to the 1969 revisions of $\$ 1232$, the holders of debt instruments which were issued at a price below the amount paid at maturity did not pay income tax on the amount of the discount until the instrument matured or was disposed of. See S. REP., supra note 2, at 146. Additionally, $\$ 1232$ was revised to regularize tax treatment of bondholders and corporate issuers. Before this revision the issuer took a ratable annual interest deduction while the holder delayed tax liability. 
holders to delay tax liability until the maturity or disposition of the bond.5

Congress' desire to tax the redemption premium on discounted preferred stock may be understood on two policy grounds. First, as Congress stated in its commentary on the Act, the premium does in some respects resemble a constructive stock dividend which has a disproportionate effect with respect to all equityholders. It has long been the policy of $\S 305(b)$ to tax disproportionate stock dividends. ${ }^{6}$ Second, it may be inferred from the similarity of new $\S 305$ rules to the taxation of original issue discount debt under $\S 1232$ that Congress wished to provide a backstop which would block access to former discounted debt results by the use of discounted preferred stock.

In the portion of the committee reports covering the $\$ 305$ reforms, Congress, elaborated on its desired revision of the taxation of discounted preferred stock by offering but one example which presents only narrow and uncomplicated technical problems. ${ }^{7}$ The subsequent, rather vague Treasury regulations ${ }^{8}$ under that section, adopted July 11, 1973, do not venture beyond Congress' narrow concept of this sort of stock. They require that the taxpayer include in gross income annually a ratable portion of the difference between the redemption price and issue price (less a "reasonable" call premium for premature redemption, presumed not to exceed 10 percent of issue price) over the period of time before the date on which the preferred stock may by agreement be redeemed by the issuing corporation.

Both Congress and the Treasury have failed to recognize, however, that very different kinds of preferred stock "may be redeemed" at a premium at some point after issuance. Some issue agreements provide only that the corporation has an option to redeem at the stated price; whether it exercises the option will depend on economic conditions and the company's success in the intervening years. If the company fares poorly, the stockholder may never realize his premium. Other issues, however, provide for varying degrees of mandatory redemption at the premium price. The regulations are written to cover both types, but they really fit only the second.

Therefore the assumption underlying the taxation of discounted preferred stock-that an increase in redemption value necessarily gives

5. INT. Rev. CODE of 1954, § 1232(a)(3), as amended by Act of Dec. 30, 1969, Pub. L. No. 91-172, \$ 413(a), 83 Stat. 610.

6. The proportionate interest test is discussed at length at p. 328 infra.

7. See note 10 infra.

8. Treas. Reg. $\S \S 1.305-1$ (c), $1.305-5$ to -8 (1973). 
a constructive stock dividend-is a generalization which cuts too broad a swath through the field of discounted preferred stock issues. It may be valid to analogize discounted preferred stock to original issue discount indebtedness where the issuer of the preferred stock is compelled to redeem at a specific date, and a sinking fund supports the redemption. However, a corporation's privilege of redemption is not the equivalent of a bondholder's power to demand repayment upon maturity.

In taxing the premium on preferred stock indiscriminately in a manner similar to the taxation of interest on original issue discount indebtedness under $\$ 1232$ of the Code, the new $\S 305$ regulations suffer from excessive simplicity. One consequence of this simplicity is confused application of the new constructive stock dividend rules to mergers and acquisitions. Issuance of discounted preferred stock is typical during corporate reorganization; in mergers and acquisitions preferred stock is most useful in reshaping ownership interests in a newly consolidated enterprise. It is therefore surprising that $\$ 305$ regulations do not specifically address tax-free reorganizations under $\S \S 368(\mathrm{a})(\mathrm{l})(\mathrm{B})$ and $(\mathrm{C})$ of the Code. When the $\$ 305$ stock dividend rules, such as they are, are applied to discounted preferred stock issued during a merger or acquisition, tax liabilities result which are at best confusing, and are at worst in conflict with longstanding tax policy.

Section 1232 of the Code, the apparent analogue to the new $\S 305$ discounted preferred rules, is rich in technical provision. By contrast, the $\S 305$ regulations lack technical detail; they do not treat problems such as cost basis adjustment or allocation of tax liability in conjunction with a preredemption sale, problems which will inevitably arise in application.

The $\$ 1232$ analogy suggests that the simplicity of $\S 305$ regulations could be cured by importation of original issue discount debt provisions into the scheme of taxing stock dividends. However, analogy to $\S 1232$ highlights the third and most basic flaw of the $\S 305$ regulations: By converting original issue discount debt concepts into constructive stock dividend rules, the new regulations fail to comport with the realities of relative risk or security which underlie the debtequity distinction. ${ }^{9}$ Each of these flaws will appear in clearer relief as we proceed.

9. See V. Brudney \& M. Chirelstein, Corporate Finance 83 n.a (1972):

Technically the claim of the debt is an obligation, since it represents an unconditional promise to pay principal and interest, which on default may be enforced by 


\section{The New $\S 305$ Provisions}

The congressional committees which were responsible for drafting the Tax Reform Act of 1969 clearly expressed the need to extend constructive stock dividend treatment to discounted preferred. Both House and Senate committee reports stated that where preferred paid no dividend, but would be redeemed after a definite period of time at a substantial premium over the issue price, the redemption premium should be taken into income on a pro rata, annual basis by treating the premium as a distribution of stock..$^{10}$

Discounted preferred stock is covered by $\S 305(\mathrm{~b})(4)$, added to the Code in 1969, which states that any distribution on preferred stock (other than antidilution increases of the conversion ratio of convertible preferred) is a distribution of property to which $\S 301$ applies, generally meaning that it will be taxed as ordinary income. ${ }^{11}$ Section 305(c) adds that the Treasury may prescribe regulations under which a redemption premium will be deemed a distribution on preferred stock. Given this broad language and the extensive powers thus delegated to the Treasury, the scope of subsequent regulations under $\S 305$ is not surprising. Section $1.305-5(\mathrm{~b})(\mathrm{l})$ states the basic rule:

If a corporation issues preferred stock which may be redeemed after a specified period of time at a price higher than the issue price, the difference will be considered under the authority of section 305 (c) to be a distribution of additional stock on preferred stock which is constructively received by the shareholder over the period of time during which the preferred stock cannot be called for redemption.

the creditor. In contrast, the preferred stock's claim is only a priority embodied in a negative covenant, which becomes enforceable only if the commons or other juniors seek to distribute earnings or assets to themselves.

Note that this comparison between debt and equity supports the quintessential distinction: In terms of investment risk, debt offers a substantially higher comparative level of safety. It is a risk factor which classically distinguishes between debt and equity.

10. The Senate Finance Committee and the House Ways and Means Committee both referred to discounted preferred directly in their reports:

Methods have also been devised to give preferred stockholders the equivalent of dividends on preferred stock which are not taxable as such under present law. For example, a corporation may issue preferred stock for $\$ 100$ per share which pays no dividends, but which may be redeemed in 20 years for $\$ 200$. The effect is the same as if the corporation distributed preferred stock equal to 5 percent of the original stack each year during the 20-year period in lieu of cash dividends. The committee believes that dividends paid on preferred stock should be taxed whether they are received in cash or in another form, such as stock, rights to receive stock, or rights to receive an increased amount on redemption.

S. REP., supra note 2, at 151 (emphasis added). See H.R. Rep., supra note 2, at 114 .

11. INT. REv. CODE of 1954, $\$ \$ 301(c), 316$, generally provide that a dividend distribution out of earnings and profits is includable in gross income. Distributions in excess of earnings and profits are applied against cost basis, with any further excess over basis taxed as gain from the sale or exchange of property. 
Clearly, discounted preferred stock will result in dividend income to its holders to the extent of the discount, even where redemption is merely permissive and not mandatory..$^{12}$

In characterizing the redemption premium on discounted preferred stock as a constructive dividend, the regulations superficially comport with fundamental concepts of stock dividend taxation. When a shareholder receives a stock dividend which "merely gives each stockholder more pieces of paper to represent the same interest in the corporation," 13 the dividend is not taxable. ${ }^{14}$ Section 305 (a) thus introduces the tax provisions for stock dividends with the general rule that a dividend of stock on stock is not generally a taxable occasion. However, a stock dividend has long been considered taxable if it effects a disproportionate distribution of the assets of the corporation to the stockholders. Section 305 (b) carves out exceptions to the general rule of nontaxability based on the rationale that the described exceptions result in disproportionate increases in certain stockholders' interests. Stock dividends are therefore measured against the longstanding "proportionate interest test," ${ }^{15}$ now codified as $\S 305(\mathrm{~b}),{ }^{16}$ to determine whether they may give rise to ordinary income.

12. A reasonable redemption premium will not result in dividend income. Treas. Reg. $\$ 1.305-5(b)(2)$ (1973). This Regulation states that a redemption premium is "reasonable" if it is in the nature of a penalty for premature redemption of the preferred stock, not exceeding "the amount the corporation would be required to pay for the right to make such premature redemption under market conditions existing at the time of issuance." While this suggests that the premium would not be available in a situation where an early redemption is planned and therefore a penalty for corporate action is inappropriate, the examples given lead one to conclude that this exception will be applied automatically to any sort of redemption. A premium of 10 percent of issue price where the corporation may not redeem for at least five years is cited as reasonable. While the examples given apply a 10 percent exception mechanically, there are implications that if it could be established that the market justified a higher premium, it would be accepted. Basically, the new $\S 305$ provisions apply only to stock distributions made after January 10, 1969. Treas. Reg. $\$ 1.305-8$ (1973) gives detailed transitional rules.

13. S. REP., supra note 2, at 150. See generally Eisner v. Macomber, 252 U.S. 189 (1920) (the classic stock dividend case).

14. The additional pieces of paper could, of course, represent an increase in the amount of earned surplus in the earnings and profit account of the issuing corporation. But even if no stock dividend had been declared to reflect such an increase, the earned surplus of the corporation would belong to the stockholders in the same proportion as if a stock dividend had been declared.

15. The proportionate interest test was first suggested by the Supreme Court in Koshland v. Helvering, 298 U.S. 441 (1936). See Helvering v. Sprouse, 318 U.S. 604 (1943). For more extensive reviews of the history of the taxation of stock dividends, see Eustice, Corporations and Corporate Investors, 25 TAx L. REv. 590 (1970); Note, An Analysis of the Taxation of Stock Dividends from 1918 to 1970, 8 DuQ. L. REv. 364 (1970).

16. The "Citizens Utility PIan" is an example of an attempt to achieve a dispro. portionate dividend of stock on stock without ordinary income consequences which is now disallowed by $\$ 305(\mathrm{~b})$ and regulations under this section. The Citizens Utility Company reorganized its common into two classes. Class $A$ holders would receive an annual dividend in common stock, while class B holders received cash. Class A stock was convertible into class $B$, but $B$ could not be converted. For the pecuniary ramifications of this device, see Lowrimore, Two Classes of Stock: One Gets Cash, One Stock Dividends: 
Section 1.305-7(a) of the Treasury Regulations details the impact of the proportionate interest test on preferred stock by demonstrating the Treasury's view that a constructive dividend on discounted preferred stock is disproportionate with respect to other shareholders (for example, holders of common stock), and is therefore a taxable distribution of corporate assets. The ordinary income result mandated by the new regulations follows from a constructive interpretation of the redemption premium on discounted preferred stock which is composed of three components. First, the premium is deemed to be a theoretical distribution of an additional amount of preferred stock as determined by an annual, pro rata formula. In the second component of the analysis the distribution of stock is equated with the distribution of a cash dividend. Thirdly, this theoretical cash dividend is constructively used by the shareholder to purchase the additional preferred stock which the redemption premium is said to represent. At several points in the following discussion this Treasury analysis will be compared against business realities surrounding specific forms of discounted preferred stock. ${ }^{17}$

\section{Mergers and Acquisitions}

The policy favoring taxation of any dividend or corporate distribution as ordinary income has long been relaxed when dealing with mergers and acquisitions: All noncash property received in such a reorganization is received either tax-free ${ }^{18}$ or as capital gain. ${ }^{19}$ How-

A Useful Tax Planning Tool, 4 J. TAx. 312 (1956). While the Treasury once allowed this device to pass muster under $\$ 305(\mathrm{~b})$, it now attacks the dividend on Class $A$ stock as a disproportionate dividend. Constructively, Class A stockholders received a taxable cash dividend, which is then reinvested in additional stock. Lowrimore, I.R.S. Attempts to Stop 2-Classes-of-Common-Tax-Saving Plan, 5 J. TAx. 178 (1956); Rev. Rul. 65-256, 1965-2 CuMr. Bull. 85.

17. The new $\$ 305$ provisions suggest that there is a buttressing of the preferred stock bail-out rules of $\$ 306$, rules which may lead to ordinary income recognition on dividends on preferred stock. See note 97 infra. This represents a new policy direction for $\$ 305$. Examples (5) and (7), Treas. Reg. $\$ 1.305-5(d)$ (1973), apply distribution of property tax rules on deemed distributions of preferred (the result of $\$ \$ 306(a)(1)(A),-306(a)(2))$ where there is evidence that management is self-serving. In example (5) a corporation issues preferred stock for $\$ 100$ which in five years is redeemable for $\$ 185$, representing a simple rate of return of 17 percent annually. Example (7) describes a preferred stock issued on common which pays a two percent rate of interest on a par value of $\$ 100$, and is redeemable in five years for $\$ 105$. The example stipulates that the initial fair market value is $\$ 50$. With the constructive redemption premium added to the two percent interest, this preferred issue returns 26 percent annually on the initial market value. Such high rates of return lead to the inference that only a self-serving management would authorize the issuance of preferred on such terms, for the purpose of bailing out earned surplus, which, of course, is precisely the concern underlying $\S 306$.

18. INT. REv. CODE of 1954 , $\$ 354$, provides generally that stock or securities received from one party to a reorganization, and exchanged for the stock or securities of a second party to the reorganization, are received tax-free.

19. INT. REv. CODE OF 1954, § 1222(9), acknowledges that capital gain arises from a sale or exchange, where the asset sold or exchanged is a capital asset. 
ever, given the anticonglomerate fever of the times during which the Tax Reform Act of 1969 was incubated, it is almost certain that Congress intended to reach discounted preferred stock issued during a reorganization with the new deemed dividend rules. ${ }^{20}$ Perhaps Congress wished to effect a result similar to that achieved under $\S 483$ of the Code, which taxes as interest a portion of the sales price of property for which payment is delayed.

Surprisingly the new $\S 305$ regulations do not deal explicitly with discounted preferred stock which is received in an exchange pursuant to corporate reorganization. As mentioned above, it appears that the Treasury responded rather woodenly to the one guiding example of the taxation of discounted preferred given by Congress. No amplification was offered to clarify problems associated with corporate consolidation. Nonetheless, it would appear that application of new $\S 305$ regulations will effect a segregation of purchase or exchange price from dividend income. ${ }^{21}$

To achieve this segregation in the context of a merger or acquisition, the premium paid upon redemption of discounted preferred stock will be analyzed by the Treasury in two steps. First, the preferred stock which the departing shareholder receives will be valued at the time of the merger or acquisition, and tax-free status will be accorded, or capital gain to the extent of that value will be assessed. In the second step of the Treasury's probable analysis, any subsequent redemption premium will be isolated and dealt with under the current regulations, resulting, of course, in annual increments of ordinary income. ${ }^{22}$

20. Treas. Reg. $\$ 1.305-7$ (c) (1973) discusses taxing a premium given in recapitalization to discharge dividend arrearages; this discussion may be taken to mean that $\$ 305$ is directed at all reorganizations. On the other hand, this could be a special exception to a rule that ordinarily $\$ 305$ is called off during reorganization. Indeed, the general silence of $\$ 305$ on the subject may have been born out of massive importation of $\$ 1232$ concepts. Curiously, Treas. Reg. $\$ 1.305-7$ (c) (1973) states that as an alternative to the procedure discussed at note 40 infra, if the gross amount of arrearages is less than the difference between exchange values, it may be used as the ordinary income figure. The excess of imputed issue price over exchange value plus dividend arrearages in that situation is not dealt with.

21. The language of Treas. Reg. $\$ 1.305-5(d)$ (1973), example (6), suggests this result. That example gives the rule that in a reorganization (including mergers and acquisitions) the exchange of preferred stock will be tax-free for the purposes of $\$ 305$ if exchanged "for a new preferred stock having substantially the same market value and having no greater call premium or liquidation preference..." The negative inference made by this example is that an exchange of preferred stock under other than the stated conditions would not be tax-free, i.e., any increment in value would be treated as "boot" which is taxable at current income rates under $\$ 356$ of the Code. It should be noted that example (6) implies that where the original security is a pre-1969 issue to which the tax reforms do not apply, this exempt status will carry over to a new security which bears substantially the same terms.

22. It is easy to construct a scenario in which the rules implied from Treas. Reg. $\$$ 1.305 .5 (d) (1973), example (6), produce inequitable results. For example, Corporation $i$ could wish to acquire Corporation $A$ by means of a $\S 368(\mathrm{a})(1)(\mathrm{B})$ (stock for stock) ac- 
In the context of corporate acquisitions, the new preferred stock rules seem to be directed against acquisitions which are financed out of the retained or future earnings of the acquired corporation, commonly called "bootstrap acquisitions." Following an unsuccessful judicial attack, ${ }^{23}$ the Treasury dealt directly with this form of financing when writing the Tax Reform Act of 1969. The overt provisions focus on debt-related means of achieving bootstrap financing, ${ }^{24}$ with $\S 305$ and the regulations under that section blocking a backdoor access to similar tax advantage by means of equity-financed bootstrap acquisitions.

Under the pre-1969 regulations, a corporate acquisition could have been financed with a relative tax advantage to stockholders by the use of discounted preferred stock. Departing shareholders ${ }^{25}$ in a $\S 368(a)(1)(B)$ reorganization would exchange their equity interest in the acquired corporation for preferred stock with a redemption premium. ${ }^{26}$ Their equity interest in the corporation would thus be limited in duration to the term of the discounted preferred stockin instances where the issuer actually redeemed the preferred-and the premium upon redemption would be taxed as capital gain. Although affected by liquidation preference, the financial conditions of the buying and acquired companies, and the terms of the redemption agreement, payment of the premium has always ultimately depended on the future profitability of the acquired company. Under both pre-1969 and current regulations, acquisitions achieved with the use of discounted preferred stock do not entail the overwhelming tax advantage to the corporation that was present in the landmark boot-

quisition, offering $B$ 's common at a substantial premium. To acquire a convertible preferred isstance of Corporation $A$ (the conversion feature of which would create a substantial increment in value as compared to previous market value, because of the preinium offered for $A$ stock) $B$ may wish to offer a nonconvertible preferred stock, issued at parity with the previous market value of the $A$ preferred, but bearing a substantial redemption premium to offset the value of the conversion feature. While the redemption premium of the $B$ preferred clearly represents the purchase of an equity interest of $A$ jreferred shareholders, the new rules mandate ordinary income treatment of the discount on redemption price.

23. Commissioner v. Brown, 380 U.S. 563 (1965) (Brown sold his business to a charitable organization which liquidated the corporation, leased the assets back to a second Brown enterprise, and relied on rentals from the lease to pay Brown the purchase price; held, that the disposition of Brown's first business was a valid sale resulting in capital gains).

24. The Act added INT. REv. CoDE of 1954, § 514, which taxes charities on business income to the extent that earnings are financed with the use of borrowed funds. See generally Jassy, The Tax Treatment of Bootstrap Stock Acquisitions: The Redemption Route vs. The Dividend Route, 87 Harv. L. REv. 1459 (1974).

25. Shareholders are departing in the sense that their equity interest is limited in duration to the preredemption period on the discounted preferred stock.

26. Proposed Treas. Reg. \$ 1.368-2(c), CCH 1974 Stand. Fed. TAx REr. I 8832A, 37 Fed. Reg. 7163 (1972), promises to reduce the importance of preferred stock in $B$ reorganizations. That regulation will require that only voting stock be exchanged for voting stock if the reorganization is to be tax-free. 
strap acquisition decision of Commissioner $v$. Brown. ${ }^{27}$ Where discounted preferred stock is used, the corporation makes one nondeductible dividend payment at the end of the period, when it redeems, rather than interest payments deductible each year. ${ }^{28}$ However, under pre-1969 rules there would still be an advantage for shareholders because the redemption premium of the equity-financed acquisition would be treated as capital gain. By the imposition of dividend treatment, the new regulations analogize the premium to interest, bringing the entire differential between redemption value and imputed issue price following reorganization into ordinary income.

Application of this constructive dividend rule to acquisitions and mergers is inappropriate. The Treasury itself has drawn a distinction between bootstrap financing and the payment of a contingent price adjustment in a merger or acquisition. Contingent price adjustments tie further increases (or, less commonly, reductions) in purchase price to the occurrence of a future event, such as success in litigation or the grant of a patent. ${ }^{29}$ When the Treasury allows such payments without tax liability ${ }^{30}$ but taxes the redemption premium on discounted preferred, it relies on a distinction which cannot be maintained. The theoretical distinction, of course, between a redemption premium on preferred stock offered pursuant to a merger or acquisition and a contingent sales price adjustment is that the redemption premium is automatic while a contingent payout depends on the uncertain course of the acquired corporation. But in reality whether redemption is automatic depends on the terms of the issuance. And some contingent payouts are in fact highly certain; they may simply be couched in terms of a contingency that is almost sure to occur.

The contingency is in theory indicative of a dispute about the

27. 380 U.S. 563 (1965).

28. See note 35 infra; cf. note 72 infra.

29. See Rev. Rul. 67-90, 1967-1 Cum. Bull. 79; Rev. Rul. 66-112, 1966-1 Cum. Bull. 68.

30. Treas. Reg. $\$ 1.305-1$ (c) (1973) exempts from deemed dividend treatment "an increase or decrease in the conversion ratio or redemption price of stock which represents an adjustment of the price to be paid by the distributing corporation in acquiring property (within the meaning of section $317(a))$." The one example given to describe this Regulation defines "adjustment" very narrowly and conventionally. In this example the conversion ratio of convertible preferred is to be increased at a later date, contingent upon the performance of the acquired corporation during the first six years of the merger. Treas. Reg. $\S 1.305-1$ (c) (1973) defines "adjustment" as a future change in redemption premium or conversion ratio which is based on a contingency that is not predictable at the time of the reorganization. Eustice, commenting before the regulations under $\$ 305$ were adopted, pointed out that even the "if-come" provision, which bases additional distributions on a contingency, would be taxable under a liberal reading of $\S$ 305 (b)(2) since the equity interests of those benefitting from the adjustment would be increased disproportionately vis-à-vis other shareholders. Eustice, supra note 15, at 545. The Treasury has not employed such a reading, however. 
value of the acquired company, ${ }^{31}$ but this hardly gives rise to a valid distinction from discounted preferred. With both a redemption premium and a contingent sales price adjustment it is likely that the departing shareholders or property owners are gambling on prospects of future profitability, either that of the acquired corporation in the case of the contingent interest, or that of the combined enterprise in the case of the preferred stock issued during reorganization. Both the contingent interest and the redemption premium may in fact have indeterminate present value, and in both instances there is a substantial (but unrecognized) possibility that the acquired company's owners are self-financing the acquisition by accepting a future promise of payment which amounts to an equity interest and which entails a degree of risk that is ordinarily associated with equity ownership. In a transaction which involves substantial investment risk, a rule which precludes the possibility of capital gains taxation is not wholly appropriate.

One might still argue that taxation as ordinary income is proper on the ground that the shareholder receiving discounted preferred stock thereby increases his proportionate interest in the enterprise. But such an approach conflicts with the usual principles underlying taxation in situations of merger and acquisition. In either the case of a contingent price adjustment or a redemption premium the proportionate interest test should be irrelevant. Mergers and acquisitions necessarily adjust the absolute equity interests of shareholders of both the acquired and the acquiring companies. ${ }^{32}$ It has always been assumed that adjustments made by mergers and acquisitions are entitled to capital gains treatment or deferral of tax as long as the adjustment conforms to the continuity of interest test. ${ }^{33}$

31. See Libin \& Moorehead, Stock Dividend Benefits Restricted but not Eliminated by the New Tax Law, 32 J. TAx. 258 (1970) (simple exchange of common for preferred in a recapitalization has similar effect of increasing the equity interest of subsequent common shareholders). See generally Murphy, Contingent Share Reorganizations, U. So. CAL. 1969 TAx INSr. 255; Tillinghast, Contingent Stock Pay-Outs in Tax-Free Reorganizations, 22 TAX LAw. 467 (1969).

32. See Courtland Specialty Co. v. Commissioner, 60 F.2d 937, 939 (2d Cir. 1932), cert. denied, 288 U.S. 599 (1933) (Augustus N. Hand, J., for the court: "Reorganization, merger, and consolidation are words indicating corporate readjustments of existing interests. They all differ fundamentally from a sale where the vendor corporation parts with its interest for cash and receives nothing more"). Despite the limited scope of Treas. Reg. $\$ 1.305-1$ (c) (1973), it does recognize the principle that upon reorganization, proportionate stock interests may be altered as between shareholders of the acquiring corporation and those who hold stock in the surviving corporation as a result of a tender offer.

33. This doctrine provides that when a shareholder's basic investment interest continues after a reorganization, tax liability is deferred. See LeTulle v. Scofield, 308 U.S. 415 (1940); Helvering v. Minnesota Tea Co., 296 U.S. 378 (1935); Pinellas Ice \& Cold Storage Co. v. Commissioner, 287 U.S. 462 (1933). See generally B. BITTKER \& J. EusticE, 
Corporations have a theoretical alternative to self-financed acquisitions, but the alternative only serves to highlight the problems with the $\S 305$ regulations. The acquiring company could negotiate a loan with an outside lender and buy out the departing shareholders' interests immediately. In this alternative situation the money that the departing shareholders receive would clearly be taxed as the sale of a capital asset rather than as a dividend distribution. ${ }^{34}$ There is no tax policy reason for treating the loan situation more advantageously than the self-financing situation. ${ }^{35}$ Indeed, the distinction between the two types of financing potentially discriminates against mergers of those companies, usually small ones, which must necessarily rely on self-financing due to the unavailability of institutional financing. ${ }^{36}$

Although Congress revised $\$ 305$ of the Code to curtail economically unsound conglomerate mergers, the current $\$ 305$ provisions are themselves economically irrational; they place undue restrictions on consolidation, restrictions which are not based on any notion of efficiency. Additionally, they are more likely to hamper small mergers than to affect the large conglomerates-the apparent targets of the 1969 Tax Reform Act.

\section{Technical Problems and the § 1232 Analogy}

\section{A. Issue Price}

The merger and acquisition context suggests certain technical problems in the application of the $\S 305$ regulations. For example, one of the most significant shortcomings of the $\$ 305$ regulations is

Federal Income Taxation of Corporations and Shareholders 14-1 to -152 (3d ed. 1971) [hereinafter cited as BITTKER \& EUSTICE]; Dane, The Case for Nonrecognition in Re. organization Exchanges, 36 TAxes 244 (1958) (defending the Code's rationale); Hellerstein, Mergers, Taxes, and Realism, 71 HARv. L. REv. 254 (1957) (questioning the basic policy). For a concise overview of tax-free mergers, see Sinrich, Tax Incentives and the Conglomerate Merger, Conglomerate Mfergers and AcQuisitions, 44 St. John's L. Rev. 1009 (spec. ed. 1970).

34. An immediate distribution of capital would constitute a stock sale, of course, causing departing shareholders to incur immediate capital gains. See Sinrich, supra note 33 , at 1010 .

35. Under INT. Rev. CODE of 1954, \$ 163, the primary relative advantage of institutional financing vis-â-vis shareholder financing through discounted preferred is that the interest paid to an institutional lender is deductible, whereas payments to preferred stockholders are not deductible. In addition, the taxation of the redemption premium at ordinary income rates, which the new regulations require, removes in part the former advantage of permitting a delayed capital gain to shareholders who self-finance.

36. Small companies which would be likely to use seller financing of acquisitions are not considered to be harmful to the competitive climate of the economy. See Brown Shoe Co., Inc, v. United States, 370 U.S. 294 (1962). In discussion of exceptions to the 1950 Amendments of $\$ 7$ of the Clayton Act, the Court noted that Congress did not wish to "impede, for example, a merger between two small companies to enable the combination to compete more effectively with larger corporations...." Indeed, such combinations might result in "stimulation to competition." Id. at 319. 
their failure explicitly to define "issue price." Issue price is a critical concept because it segregates the equity and dividend elements of discounted preferred by establishing the extent of the discount which will be taken into ordinary income. Yet the method of determining issue price may only be inferred from an opaque reference in two examples in the regulations. They suggest that issue price will be equated with either the price paid for a new preferred stock issue, or with the fair market value of preferred immediately after issuance. However, the examples give no means for choosing between the two standards. ${ }^{37}$ These standards may be workable for a simple public issue of discounted preferred, but they produce confusion in complicated transactions such as those associated with reorganizations, or in closely held issuances where the market is not a factor.

As an example of this unworkability, consider a $\$ 368(\mathrm{a})(1)(\mathrm{B})$ acquisition of Corporation $A$ by Corporation $B$, where $A$ has outstanding a convertible preferred issue, sold to the public a year earlier at $\$ 80$, currently trading at $\$ 85$. In exchange, $B$ offers a convertible preferred with a liquidation value of $\$ 90$, redeemable in 5 years for $\$ 110$. Exchange takes effect on a Friday, and due to a political setback of $B$ 's international aspirations over the weekend, the market discounts conversion rights and likelihood of redemption, valuing the $B$ preferred at $\$ 50$ on Monday's opening. Should the issue price of $B$ 's preferred be set at $\$ 90$, its stated value on Friday; at $\$ 50$ (producing a $\$ 12$ constructive annual dividend over the next 5 years), the market value on Monday; at $\$ 85$, the value of what was "paid" for the stock in the form of exchange; or $\$ 80$, the cash originally paid out for the $A$ preferred?

The implied rule that issue price equals fair market value of discounted preferred immediately after reorganization is inadequate. It presumes that there will be an active market for such stock, and that the market will react only to future rates of return. Quite possibly a small group of shareholders will receive the entire issuance, rendering useless any open market standard. If redemption is not mandatory, participation in future income of the consolidated corporation, as represented by the discount, may be so speculative that

37. Treas. Reg. $\$ 1.305 \cdot 5(\mathrm{~d})$ (1973), examples (5), (7). Example (5) discusses a preferred stock issue which is apparently, but not clearly, offered to the public. Example (7) describes a hypothetical preferred with a stipulated "fair market value." While there is no discussion of how this value is ascertained, one must assume that general fair market value principles will take effect. Since the contemplated rate of return on the stock in both examples is very high, both of these examples suggest self-dealing by management which would make a fair market value meaningless or unascertainable. These examples are limited by their facts-it is difficult to argue that they state a solid, broadly applicable rule. 
the market gives it minimal value. ${ }^{38}$ In addition, the immediate fair market value will reflect the market's expectation about the newly organized enterprise: where such expectation is unfavorable, the redemption premium will be overstated, to the extent which the market undervalues the stock. Conversely, the redemption premium will be understated when market expectations are favorable.

Similarly, it is unsound to set issue price equal to the price paid for the discounted preferred issued in a reorganization. By equating issue price with the value of the stock surrendered, any sweetener or market reaction will also distort the results.

Another provision of the regulations might suggest a means for determining issue price. In the limited instance of a recapitalization in discharge of dividend arrearages, ${ }^{39}$ the regulations give the faintest hint that the issue price of preferred stock given in a reorganization may be determined by its par value as represented by the stated liquidation preference. ${ }^{40}$ The hint is tempting, but the temptation should be resisted. In a merger or acquisition an increase in par value has a greater identity with equity than such an increase given to discharge dividend arrearages. This is so because the additional face value of the stock is less likely to be a substitute for dividends and more likely to represent a sweetener added to the acquisition price or an offset for the departing shareholder's increase in investment risk. Additionally, there is no rule which prevents the typical practice of assigning meaninglessly low par values, or freely varying liquidation rights.

The regulations for $\$ 305$ thus give rise to important problems of interpretation. It seems promising to try to cure them by reference or analogy to $\S 1232$ of the Code, a much more detailed provision than the $\S 305$ regulations. After all, by treating the redemption premium as a constructive dividend rather than as a payment of the purchase price, the Treasury is imposing recognition rules on preferred stock which substantially resemble the treatment of original issue discount

38. To tax appreciation on such a speculative position offends the usual concept that risk implies equity, and equity implies capital gain.

39. When dividends are omitted, cumulative preferred stock accumulates the arrearages as a liability against the corporation which must be repaid, terms of repayment depending on contract. Often in a recapitalization such arrearages are eliminated by exchanging the old preferred for a greater amount of new preferred.

40. In a $\$ 368(\mathrm{a})(\mathrm{I})(\mathrm{E})$ recapitalization, the increase in proportionate interest attributable to dividend arrearages is to be determined by the difference between the issue price of the preferred stock surrendered and the fair market value, or the liquidation preference of the stock received, whichever is greater. Treas. Reg. $\$ 1.305-7$ (c) (1973). While this is a circular definition of issue price, liquidation preference is given as an alternative to fair market value. 
debt under $\$ 1232$ of the Code. And, as Professors Bittker and Eustice note in their treatise, " $[p]$ referred stock 'retirement premiums' bear a close functional relation to the debt issue discount rules of $\S 1232$ (a)(3) ... and [the relevant provisions of $\$ 305$ ] can be viewed as a backstop to protect avoidance of these provisions." ${ }_{11}$

Section 1232 defines issue price with great precision. When a discounted bond is offered to the public, the initial offering price is equated with the issue price. In the case of privately placed debt securities, the price paid by the first buyer is taken as the issue price. And, when an original issue discount bond is exchanged for stock or other securities which are traded on an established securities market (other than an exchange pursuant to $\S 368(a)(1)$ ) the fair market value of the property exchanged determines the issue price. ${ }^{42}$ Curiously enough, when the bond is exchanged for stock during a corporate reorganization, issue price is equated with stated redemption price at maturity, ${ }^{43}$ which results in a reinstatement of former original issue discount rules. ${ }^{44}$ That is, taxation is deferred on the entire premium until it is actually received upon redemption or disposition.

\section{B. Transition Problems}

Transition to current $\S 305$ rules presents a second technical problem inadequately treated by the regulations. Under the liberal transition rules of amended $\S 305,45$ it is probable that some issuances of discounted preferred stock will escape deemed distribution treatment. The regulations, however, give no guidance on the treatment of pre1969 discounted preferred stock exchanged for new discounted pre-

41. BitTKER \& Eustice, supra note 33, at 7-77 n.132. A word of caution about analogizing discounted preferred to original issue discount indebtedness: While there is a great deal of similarity between the two forms of securities and between the regulations dealing with each of them, neither the regulations nor the Code itself cross refcrence $\$ 305$ to $\$ 1232$. Hence, any comparison is merely suggestive.

42. INT. REv. CoDE OF 1954, \$ 1232 (b)(2).

43. Although both the original House and Senate versions of the Tax Reform Act of 1969 included debt issued pursuant to a tax-free reorganization within the coverage of amended $\$ 1232$, such coverage was deleted by the Senate during floor debate. See BITTKER \& Eustice, supra note 33, at 4-58. Anomalously, therefore, a very potent anticonglomerate debt provision was lost, while $\$ 305(\mathrm{~b})(4)$ and related regulations, its equity counterpart, are preserved. The regulations therefore have explicitly exempted from new original issue discount accrual rules all discounted debt received in a corporate reorganization unless it is received in exchange for discounted debt which already falls under the new tax schema. Treas. Reg. $\$ \S 1.1232-3(\mathrm{~b})(1)$ (iv) (1972); 1.1232-3(b)(2)(iii)(d) (1972). It is likely that old case law will attach, stipulating that upon disposition the difference between basis and disposition price will result in ordinary income, i.e., gain from the sale of noncapital property. See, e.g., United States v. Midland Ross Corp., 381 U.S. 54 (1965).

45. Treas. Reg. $\$ 1.305-8$ (1973). 
ferred after 1969.46 Section 1232 provides that discounted debt whose basis carries over to pre-1969 original issue discount securities will be afforded the more favorable tax status of the exchanged debt issue. Regulations under $\$ 1232$ further provide that basis and discount characteristics of these debt securities are not disturbed when the securities are acquired from a decedent..77

\section{Pre-Maturity Dispositions and Other Problems in Computing the Premium}

Probably the most difficult tax problems which practitioners will confront with the new discounted preferred regulations involve prematurity dispositions ${ }^{48}$ - problems such as allocating cost basis or allocating constructive income. Here importing the technical detail of $\S 1232$ can be of real help. The market value of discounted preferred will often increase disproportionately so that in many cases the actual redemption premium which the pre-maturity buyer receives will be less than the pro rata amount of premium which the original holder of the discounted preferred stock had not yet accrued as ordinary income. In such a case, $\$ 1232$ provides that the purchaser must pay ordinary income tax only on ratable portions of the discount actually received..$^{49}$ On the seller's side, $\$ 1232$ provides a precise formula to determine the amount of constructive interest in a pre-maturity sale of discounted indebtedness. ${ }^{50}$ Section 1232 also contains complicated provisions governing the extent to which an original issue discount holder may realize capital gain upon sale or exchange. ${ }^{51}$

These $\S 1232$ provisions will be useful for simple transactions that fall within $\S 305$. But discounted preferred stock does not inevitably

46. Given the silence of the regulations, it is certainly quite possible that the courts would give the phrase "issued after January 10, 1969" a broad meaning, extending the new regulations without exception to any preferred stock issued after that date.

47. INT. Rev. CoDE of 1954, \$ 1232(a)(3)(C); Treas. Reg. $\$ 1.1232-3$ (b) (2)(iii) (1972). By implication, Treas. Reg. $\$ 1.305-5$ (d) (1973), example (6), provides carryover treatment. See note 21 supra.

48. All nine examples of discounted preferred stock which appear in the regulations are based on the assumption that the initial holder will be the holder at maturity.

49. INT. REv. CODE OF 1954, § 1232(a)(3)(B).

50. Id. $\S 1232$ (a) (3)(A) provides that for determining the ratable portion to be taken into income, a monthly basis of calculation shall be used. The monthly periods are established by the date of issuance of discount indebtedness to the original holder. If a discount bond is acquired in any way other than original issuance, such as by purchase on the market, provision is made for allocation of a fractional monthly portion of the pro rata annual amount between buyer and seller.

51. Id. $\$ 1232(a)(2)$ provides that gain derived from the sale of a bond held for a period greater than six months, unless there can be shown an intention on the part of the issuer to redeem before maturity, is capital gain. Any portion of the selling price which has already been included in income shall not be subject to double taxation as a subsequent capital gain. (Such a provision is notably lacking under $\$ 305$.) Additionally, any purchase price premium may be amortized and is not subject to gains treatment. 
mature the way bonds do. In fact, discounted preferred stock issues commonly provide for gradual partial redemption of the stock over long periods of time. Such a feature will raise questions about allocating basis and determining the discount. ${ }^{52}$ The original issue discount debt regulations provide some assistance by allowing for adjustment of the debt issue's basis in partial redemption, ${ }^{53}$ but they do not solve all of the problems.

52. This problem and others are demonstrated by AMErican Findacial Corp., PrELIMINAkY Prospectus (May 11, 1973), which sets forth the terms upon which American Financial Corporation agreed to redeem discounted preferred stock which was offered in exchange for shares of National General Corporation. The prospectus states:

AFC will be obligated to retire, at $\$ 14.15$ per share plus accrued dividends, $10 \%$ of the number of preferred shares originally issted.... in each of the years 1983 to 1992 inclusive, subject to credits at AFC's option for the number of shares purchased or redeemed, otherwise than pursuant to this requirement. In addition, AFC at its option may retire, at the same price, up to an additional $10 \%$ of the shares in each of the years 1983 to 1992, exclusive, such option right of redemption being cumulative.

Id. at 12. The prospectus goes on to provide that the preferred is callable at the option of the issuer in 1978 at $\$ 15.88$ per share, and is callable any year thereafter at a price which decreases 10 cents per year.

The American Financial Corporation offer illustrates as well the difficulties of computation when only a portion of the outstanding shares will be redeemed in a given year. In such cases it would be inaccurate to calculate pro rata amounts of redemption simply by dividing the total redemption premium by the total number of years until complete maturity. An exaggerated example illustrates this observation. Suppose a company issues $X$ shares of preferred for $\$ 100$, promising to redeem half for $\$ 100$ in 10 years, the other half for the same amount in 20 years. Thus there is a total premium of $\$ 100$ which, divided by 20 years (the amount of time until all stock is redeemed) results in a pro rata yearly figure of $\$ 5$. But it would seem more logical to say that $\$ 50$ of the total $\$ 100$ premium was received during the first 10 years (\$5 per year for years one through 10 ) while the remaining $\$ 50$ of the premium was received over 20 years. Thus, a total of $\$ 7.50$ is distributed to the shareholders for the first 10 years, and only $\$ 2.50$ per year is distributed during the last 10 years. To the extent that the current regulations implement a crude calculation of the average yearly distributions, resulting above in the $\$ 5$ figure, there is delayed tax liability. The result is the same, with more complicated computational problems, in the American Financial situation where redemption is spread out over 10 years.

There is thus great uncertainty about the exact terms under which redemption will actually take place, given the number of options open to the issuer. It is not clear which of the options will be used by the Treasury in determining the amount of redemption price which is to be the basis for establishing a premium. Nor is it clear how long the Treasury will calculate the preredemption period to be.

The examples in the regulations contemplate only a very simple redemption plan and do not reach these complex issues. The congressional committees gave the example of preferred stock issued for $\$ 100$, redeemable in full in 20 years for $\$ 200$, and paying no dividend in the meantime. The annual deemed distribution was obtained by dividing the total premium of $\$ 100$ by 20 years, giving a distribution of $\$ 5$ per year. See note 10 supra. The distribution in the example given by Congress is computed on the basis of simple as opposed to compound interest rates. In the case of a long preredemption period, the difference between simple and compounded rates of interest could be substantial. Thus the regulations embody an added disincentive to the use of discounted preferred, because income devices which allow compounding of interest would be relatively more attractive to the investor. In the example given by the congressional committees, the rate of imputed income at which the issue is being taxed exceeds the actual rate of return.

53. Treas. Reg. $\S 1.1232-3 A(e)(2)(i i i)(1972)$ stipulates that if a portion of an obligation (other than a single obligation having serial maturity dates) is redeemed prior to the stated maturity date of the entire obligation, the adjusted basis of the remaining portion shall be equal to the adjusted basis of the entire obligation minus the amount paid upon the partial redemption. 
Debt issues bear a definite maturity date, but this is not necessarily true of redeemable discounted preferred stock. Thus, it is unclear how the regulations will be applied to discounted preferred which increases in redemption price but does not evidence a fixed corporate obligation to redeem..$^{54}$ The problem of discounted preferred stock with a nonmandatory redemption agreement reflects perhaps the most substantial warp in the thinking which underlies new preferred stock rules. Where redemption is exercised at the discretion of the corporate issuer, there is little justification for taxing the preferred stockholder on "dividend income" which he never has power to demand and may never receive. The problem is less severe in the case of a close corporation whose discounted preferred shareholders may have considerable influence over the corporation's decision to redeem. On the face of the regulations, however, it seems inevitable that all preferred shareholders will be confronted with annual accrued tax liability.

A similar problem is presented by the preferred issue which has a sliding-scale redemption provision. For the first several years the redemption value of such an issue may increase after which it decreases. If the $\S 305$ rules are to be applied consistently, the increasing redemption premium will be treated as a constructive dividend. The declining redemption value will thus create an anomalous deduction offsetting income. In this situation, as in the instance of nonmandatory redemption, a possible solution would be to consider the transaction open-ended, delaying recognition until the actual outcome of the redemption feature can be determined. ${ }^{55}$ More standard forms of preferred stock, such as cumulative issues which add unpaid dividends to the redemption price, ${ }^{56}$ or those which permit early re-

54. Treas. Reg. $\$ 1.305-5(d)$ (1973), example (5), discussed in note 37 supra, describes a preferred issue which contains a term stipulating that during the unlimited number of years before the preferred stock is redeemed, the redemption price shall increase by a given amount.

55. See Burnet v. Logan, 283 U.S. 404 (1931). This is a result which for reasons of loss of revenue the Treasury is understandably hesitant to permit.

56. One frequently encountered term of a discounted preferred issue involves the provision for redemption at par plus accumulated but unpaid dividends. This apparent: increase in the redemption value, which is analogous to a discount, is given incomplete attention by the regulations, which provide only for discharge of dividend arrearages upon recapitalization. See Treas. Reg. $\$ 1.305-7$ (c) (1973). Here again, the most reasonable resolution seems to be open-ended characterization of the redemption feature. See Committee on Corporate Taxation of the N.Y. Bar Ass'n Tax Section, Comments on Proposed Regulations under Section 305 of the Internal Revenue Code of 1954, 49 TAxes $460,487(1971)$. 
demption at the option of the issuer ${ }^{57}$ create similar problems of indeterminate tax status which cannot be solved by reference to $\S 1232$.

\section{Adjustments to Basis}

In the case of original issue discount indebtedness, both Code and regulations state a simple, precise formula for increasing the debtholder's cost basis. The basis is adjusted upward annually as interest -a pro rata portion of the discount-is constructively taken into income. ${ }^{58}$ This is necessary to prevent double taxation of the discount, once as income and again as capital gain upon redemption. Similarly, a discounted equity instrument requires provisions which prevent double taxation. Section 305 and attending regulations, however, do not make adequate provision for the adjustment of cost basis of discounted preferred.

The basis provisions under $\S 301$ govern $\S 305$ basis questions because a disproportionate constructive stock dividend is defined as a $\S 301$ distribution. Section 301, however, produces a complicated result that differs markedly from the straightforward adjustment on the $\$ 1232$ model which one would expect.

Section $301(d)(1)$ of the Code gives the fundamental rule that "the basis of property received in a distribution to which subsection (a) applies shall be ... the fair market value of such property." "s If applied by its terms, $\$ 301$ will require a determination of the fair market value of a highly elusive entity; the market value of each

57. Redemption premiums may be conceived which permit early redemption at the option of the issuer. This situation will raise a question of interpretation when redemption is made prior to the time when the premium has been taken entirely into income. Would the redemption premium be capital gain or ordinary income to the holder? Since the regulations provide no rules regarding cost basis adjustment in such a situation, premature payment of the redemption premium could give rise to capital gain, to the extent that the redemption price exceeds the adjusted basis as determined by $\$ 301$. However, in the discussion of acceptable redemption premiums for premature redemption, the regulations seem to be saying that no more than a 10 percent premium will be accorded capital gains treatment. See Treas. Reg. $\$ 1.305-5(b)(2)$ (1973). Probably any premium in excess of 10 percent will be taken to be a deemed disproportionate distribu. tion, resulting in dividend income. This may annoy one's sense of order in that a cost basis adjustment under $\$ 301$ must be made in improper sequence, i.e., after the stock has been disposed of.

58. INT. REv. CoDE of 1954, \$ 1232(a)(3)(D); Treas. Reg. \$ 1.1232-3A(c) (1972).

59. Treas. Reg. $\S 1.301-1$ (b) (1955) goes on to add that if the distribution is not made in cash, fair market value is determined as of the date of distribution. Regulations under $\$ 305$ seem to endorse the fair market value approach of $\$ 301$. See, e.g., Treas. Reg. \$ $1.305-5$ (d) (1973), examples (1), (7). However, Treas. Reg. $\$ 1.305-5$ (d) (1973), example (5), introduces confusion; in that example the value of the redemption premium is determined by redemption price rather than by fair market value. It should be noted that the text discusses the typical case of basis adjustment for individual shareholders. However, differing basis results for corporate distributees are given in INT. REv. CoDE of 1954, $\$ \S$ $301(d)(2)-(4)$. 
deemed distribution on the discounted preferred will have to be evaluated at the time it is constructively received by the taxpayer. The value of the deemed distribution will probably be ascertained by considering the fair market value of the taxpayer's total holdings of discounted preferred at the time when the Treasury deems that a distribution takes place. In the instance of a preferred issue with a long preredemption period and nonmandatory redemption, the market will probably discount the likelihood that the stock will be redeemed. In the early years the fair market value of stock constructively received may be less than the pro rata amount of the redemption premium. Certainly, the market price of the preferred will vary with market conditions such as the prevailing interest rate. A convertible preferred issue may also fluctuate as the common stock of the corporation fluctuates. Where there is a substantial increase in market value, strict adherence to $\S 301$ basis rules indicates an expansion of cost basis which is disproportionate to constructive dividend income. Conversely, where the preferred stock's market value declines, the basis will be increased by less than deemed dividend income.

Regulations under $\$ 305$ state no explicit rule about the determination of the amount which is subject to potential dividend treatment. However, the examples given lead to the inescapable conclusion that equal pro rata amounts of the redemption premium value will be taken into income annually, rather than any amount determined by fair market value. ${ }^{60}$ Thus the cost basis of each share of discounted preferred will be adjusted, but the adjustment will bear only a haphazard relation to the amount of constructive ordinary income on which the recipient pays taxes annually. Section 1232 obviously provides a far more logical treatment-basis adjustments should be exactly equal to deemed dividends-but neither Code nor regulations presently assure this result. The graft of debt rules onto an equity transaction in $\S 305$ thus results in an oversimplified assessment of the value of the deemed distribution.

Section 301 contains other distinctive provisions which yield curious results when applied to discounted preferred, ${ }^{61}$ even though they

60. The examples given in Treas. Reg. $\$ 1.305-5$ (d) (1973) all discuss the constructive dividend, when applicable, in terms of a pro rata portion of the premium rather than in terms of the fair market value of the deemed distribution.

61. See H.R. REP., supra note 2 , at 113 , which in casual discussion confines its attention to "dividends" on preferred. The report states that the Ways and Means Committee "believes that dividends paid on preferred stock should be taxed whether they are received in cash or in another form, such as... rights to receive an increased amount on 
may make sense for less exotic forms of disproportionate (hence currently taxed) stock dividends. In contrast to $\$ 1232$ which taxes pro rata annual interest on discounted debt regardless of the financial status of the issuer, deemed $\S 301$ equity distributions may give rise to no current taxation, and may indeed reduce cost basis. As stipulated by $\$ \$ 30 \mathrm{l}$ and 316 , where a corporation has no current or retained earnings, a distribution to the stockholders is applied as a reduction of basis, any excess over basis being taken as capital gain. Therefore under present rules deemed $\S 301$ distributions on preferred may lead to widely disparate results. The stockholder could in a given year experience upward or downward basis adjustment. The deemed distribution could be taken as dividend income or, where the issuer has no earned surplus and basis is reduced to zero, the deemed distribution might even give rise to a capital gain. Moreover, where the corporation is not required under the agreement to redeem the stock, it is not inconceivable that $\$ 305$ might force a shareholder to accrue income which will never be realized as a cash redemption.

One possible path out of the forest would be adoption of a per se rule under $\$ 301$ or $\$ 305$ which equates basis increments on discounted preferred with pro rata yearly distributions of the redemption premium. Such a rule, however, would still not restore justice in situations where the value of the preferred stock declines substantially, thus making ultimate redemption highly unlikely. When a discounted preferred issue suffers severe reduction in value, the pro rata constructive dividend rule of $\S 305$ as it is now constituted may force a shareholder to realize dividend income ${ }^{62}$ even though the preferred stock promises to be ultimately unprofitable. ${ }^{63} \mathrm{An}$.increase in the eventual capital loss, which would be the result of a per se basis ad-

redemption." However, INT. REv. CoDE of 1954, $\$ 301(c)(1)$, provides that "that portion of the distribution which is a dividend (as defined in section 316 ) shall be included in gross income." Ixr. Rev. CoDE of 1954, \$ $316($ a), defines a "dividend" as any distribution of property which is made out of current earnings or earnings and profits accumulated after February 28, 1913. Section 301(c)(2) goes on to provide that additional amounts of distribution shall be applied against basis in the stock, and amounts in excess of basis shall be treated as capital gain.

62. Realization depends, of course, on whether the corporation has current or retained earnings at the time of the distribution, as stipulated by INT. REv. CODE OF 1954, $\$ 316$.

63. For example, a corporation may be on the verge of bankruptcy, owing creditors interest and impending maturity payments on bonds which have a higher priority than preferred stock in the event of bankruptcy and liquidation. In such a case, the market would assign only an extremely minimal value to the corporation's discounted preferred stock. Nonetheless, the preferred stockholders, according to the inevitable rule of the $\S 305$ regulations, realize income on the basis of previous issue values which bear no relevance to the present. 
justment, would not offset the tax loss incurred because the shareholder paid taxes on fictitious dividend income. ${ }^{84}$

Section 1232 provides an analogy useful for solving some of the interpretive problems created by the simplicity of the regulations under $\S 305$, particularly when the discounted preferred issue involved bears a great many functional similarities to original issue discount indebtedness (e.g., when the preferred carries a mandatory redemption date). But in a wide variety of situations, such as issuance during an acquisitive reorganization, a substantial drop in market value, or permissive redemption, a large number of problems remain.

\section{Obscuring the Distinctions Between Debt and Equity}

The failure of $\S 305$ regulations to address the wide variety of technical problems which arise under the new constructive dividend scheme for discounted preferred stock demonstrates the folly of treating an equity interest, which preferred stock represents, as a debt security. The less that discounted preferred stock resembles original issue discount indebtedness, the greater the problems of interpretation. Resolution of problems with discounted preferred depends largely on sorting out this essential distinction between investment instruments.

Debt is always limited in its term, and return on debt is generally considered to be the payment of interest which must be taken into ordinary income. ${ }^{65}$ An equity interest in a corporation, however, cannot be viewed so simply. Payments on equity are not always payments of dividends; they may reflect an increased value of the capital. Equity is usually not limited in its term of existence, and equity does not represent the relative security and priority of debt. ${ }^{66}$

64. To carry an absurdity to the extreme, one may even conceive of a stock with negative value, should annual deemed dividend distributions exceed probable redemption value.

65. However, $\$ 1232$ itself is ambiguous on this point. See BITTke \& Eustice, supra note 33, at 4-57: "One unfortunate shortcoming of the new issue discount provisions is their failure once again to clarify the character of issue discount income." It is unclear whether the new provisions treat the discount as interest per se, or merely ordinary gain. By importing $\$ 1232$ rules into $\S 305$, the Treasury also seems to have imported the ambiguous tax status of the discount.

66. Such statements are generalizations. If risk were to be measured on an absolute scale, certainly the common of some blue chip companies would offer greater investment safety than the debt of less established firms. It should be hoped that the regulations under $\$ 385$ will define risk in terms relative to the various securities offered by each corporation, rather than on an absolute standard (such as a fixed debt to equity ratio). If the standard is to be absolute, the freedom of less well-heeled companies to characterize their own securities as they wish will be severely impaired. 
The Tax Reform Act of 1969 amended the tax liability of the holder of original issue discount debt by causing the holder to take into income annually a pro rata share of the original issue discount. The decision to alter this treatment of the debtholder was based on sound policy grounds. ${ }^{07}$ The most fundamental objection made to pre-1969 taxation of original issue discount indebtedness was that the treatment of the debtholders did not parallel the tax deductions taken by the issuer. ${ }^{B 8}$ Holders of discounted debt encountered liability for income tax only upon redemption or disposition of their bonds, ${ }^{60}$ but issuers took annual interest deductions on a pro rata share of the discount over the life of the debt. Original issue discount debt was also open to tax fraud because holders of the security did not always take the amount of the discount into income upon redemption. ${ }^{70}$ And general anticonglomerate policy regarded the deferral of income recognition as a tax advantage which encouraged acquisitions. ${ }^{71}$

By using the $\S 1232$ analogy to define $\S 305$ concepts, the Treasury now imposes upon holders and issuers of discounted preferred the same anomalous treatment that motivated reform of $\S 1232$, but the burdens are reversed. Holders of discounted preferred stock are taxed like holders of debt because they constructively receive ordinary income each year, but issuers of discounted preferred receive equity tax treatment because they cannot take an annual deduction for the deemed distributions. ${ }^{72}$ When redemption premiums on preferred were formerly allowed capital gains treatment, there simply was no problem of nonparallel treatment as between issuer and discounted preferred holder which suggested the presence of tax delay or tax avoidance. The objection made to the accrual of the preferred shareholder's tax liability which new $\$ 305$ rules impose is primarily an objection to the timing of the tax payment. The greater investment

67. See Landis, Original Issue Discount After the Tax Reform Act of 1969, 24 TAx LAw. 435, 441 (1971); H.R. REP., supra note 2, at 107-08.

68. H.R. REP, supra note 2, at 109; S. REP., supra note 2, at 146-47.

69. In 1965 the Supreme Court established that disposition of discounted bonds gives rise to ordinary income rather than capital gain to the extent of the discount. United States v. Midland Ross Corp., 381 U.S. 54 (1965).

70. Under the new law, isstuers are now required to return an information form (Form 1099) annually to both the debtholder and to the Government where the pro rata amount of constructive interest exceeds $\$ 10$. INT. REV. CODE of 1954, $\$ 6049$ (a).

71. H.R. REP., supra note 2, at 103. Ironically, original issue discount used in a corporate reorganization is sheltered from new $\$ 1232$ rules, as a result of last minute changes in the Tax Reform Act of 1969. See note 43 supra.

72. However, under Treas. Reg. $\$ 1.312-1$ (d) (1955) corporations may reduce their carned surplus account to the extent that shareholders must include deemed distributions in gross income. 
risk of preferred stock vis-à-vis debt is sufficient to raise the argument that equityholders should not be taxed until cash is actually received..$^{73}$

Moreover, as has been discussed, in the context of corporate mergers and acquisitions distinctions which have important tax consequences are seemingly ignored by the new discounted preferred regulations. ${ }^{74}$ The Code draws a distinction between the receipt of cash or cash equivalents on the one hand and of equity instruments or most other securities on the other ${ }^{75}$ When a departing shareholder receives as part of an acquisition offer a promise of a deferred payment of purchase price which is in the form of a redemption premium, the new regulations essentially regard the premium as a cash equivalent. The regulations treat the premium as analogous to boot, ${ }^{70}$ the

73. The question of how shareholders should be taxed upon receipt of the redemption premium is a difficult one. Cash basis principles of accounting require that at the very least, ordinary income recognition should be delayed until redemption (partial redemptions could be devised to lessen the sting of one huge addition to ordinary income). Where the investment risk is substantial (e.g., where redemption is nonmandatory), there would be a good argument that the return represented by the redemption premium should be taxed as capital gain.

74. The distinction is in fact made for the sake of reorganizations generally. Thus it is equally critical in recapitalizations and incorporations whether a debt or equity instrument is regarded as a cash equivalent.

75. INT. REv. CODE oF 1954, $\$ \$ 354(a)(1), 361(a)(1)$ grant tax-free status to the transfer of securities or stock of one corporation for similar securities or stock of another, in. cluding inter alia transfers made in mergers and acquisitions. Judicial interpretation and the regulations have restricted the meaning of "securities" to exclude short term notcs (which have close equivalence to cash). See Pinellas Ice \& Cold Storage Co. v. Commissioner, 287 U.S. 462 (1933); BITTKER \& Eustice, supra note 33, at 3-17. The Treasury has responded with Treas. Reg. $\$ 1.368-1(b)(1955)$. When cash or the equivalent of cash is received in a reorganization, it is treated as "boot," the taxation of which is to be de. termined by the character of the particular asset. BrTTkER \& Eustrce, supra note 33, at 3-20.

76. The inferred analogy between boot and redemption premiums is for the most part conceptual rather than technical. Were the premium openly identified with boot, INT. REv. CODE OF 1954, $\$ 356$ would mandate immediate tax liability rather than taxation during the whole of the preredemption period. However, Treas. Reg. $\$ 1.305-7$ (c) (1973) stipulates this result in certain $\$ 368(a)(1)(E)$ reorganizations. Treas. Reg. $\$ 1.305 .7$ (c)(1)(ii) (1973) states that in a recapitalization "an increase in a preferred shareholder"s proportionate interest occurs in any case where the fair market value or the liquidation preference, whichever is greater, of the stock received in the exchange...exceeds the issue price of the preferred stock surrendered." Immediate tax consequences follow such an increase in proportionate interest. Application of these recapitalization provisions to B or C reorganizations could similarly render as boot a substantial portion of the redemption premium.

Determination of the "issue price" of preferred stock issued during a $\$ 368(\mathrm{a})(\mathrm{l})$ (B) or (C) reorganization is not clear under the $\$ 305$ regulations (of course, fixing the issue price determines the extent of the premium). Were original issue discount debt rules followed, Treas. Reg. $\$ 1.1232-3(\mathrm{~b})(2)(\mathrm{iii})(\mathrm{b})$ (1972) suggests that issue price equals fair market value of securities given up in the exchange. Should the indications given by Treas. Reg. $\$ 1.305-5$ (d) (1973), example (7), be amplified to cover $B$ and $C$ rcorganizations, issue price would equal fair market value of preferred stock immediately after distribution. Given favorable market conditions immediately following reorganization, the new version of the proportionate interest doctrine may characterize preferred stock as boot. 
character of which resembles the payment of dividends and gives rise to ordinary income. ${ }^{77}$

The new original issue discount rules for debt securities themselves distort the notion of cash equivalence. ${ }^{78}$ By forcing the holder of discounted debt to recognize current income on a premium which may not be received for many years, ${ }^{70}$ they appear to equate an increased interest in a redemption premium with the current receipt of cash. If this concept does not explain the logic of the section, one is left to conclude that the original issue discount provisions require cash basis bondholders to accrue income which will be received in a future tax period. The same observation may be made with greater force about discounted preferred stock. The new provisions which tax stockholders currently on a redemption to be received in the future can be said either to compel cash basis stockholders to accrue income, ${ }^{80}$ or to view pro rata annual portions of the premium as being sufficiently similar to cash currently received so that inclusion in gross income is required.

In short, there appear to be a number of ways the $\S 305$ regulations treat discounted preferred stock as though it were a short term debt interest in a corporation. Not only does such treatment give rise to several anomalies outlined earlier, it also conflicts, apparently inadvertently, with the efforts Congress made in other areas of the Code to distinguish more accurately between debt and equity.

Section 385, which was added to the Code in 1969, gives broad power to the Treasury ${ }^{81}$ to issue regulations which will define the debt or equity status of investment instruments for all purposes of the Code..$^{82}$ Congress has suggested that the Treasury include among

77. The Treasury's position seems premised on the notion that the redemption premium has present value at the time of issuance of the preferred stock. The regulations may be construed as taking the position that the premium is of no value upon reorganization, but consists entirely of future dividends. See p. 330 supra. A middle position is argued at p. 352 infra, that the redemption premium represents dividend incomc in part and purchase payment in part; cf. note 73 supra.

78. See generally Landis, supra note 67.

79. Of course the income could be received immediately upon a pre-maturity sale. But this same argument could be used to justify taxing a distribution of common on common, as in Eisner v. Macomber, 252 U.S. 189 (1920).

80. Cash basis accounting is codified in INT. Rrv. Cone or 1954, $\$ \S 446$ (a), 451(a).

81. At this time it would be inaccurate to assert that a sharp debt-equity distinction has emerged from the Tax Reform Act of 1969. INT. REv. CoDE of 1954, $\$ 385$ places a great deal of responsibility on the Treasury to write regulations which make the debtequity distinction. The Treasury has not yet responded to this mandate.

82. Some light has already been shed on the matter. INT. Rev. CodE OF 1954, § 279 was enacted in 1969 to give the Treasury a means of denying interest payment deduction claimed for debt which bears such a substantial risk that it is in fact equity. Four features must be evident before interest may not be deducted: The purported debt must be subordinated; there must be a provision for conversion into common; the debt- 
the factors which may be used in these regulations: the existence of a fixed rate of interest, the existence of a definite promise to repay principal at a specific maturity date, subordination or preference to other indebtedness, the debt to equity ratio of the issuer, convertibility into common, and the relationship between holdings of stock and holdings of the purported debt. ${ }^{83}$

Section 385 and related Code provisions clearly envision a risk standard which will distinguish between debt and equity. According to this standard, the elements of risk necessary for equity characterization are associated to some extent with preferred stock. ${ }^{84}$ Preferred is subordinated to general creditors, the payment of dividends is contingent upon corporate profits, and holders of preferred bear a substantially greater risk than holders of indebtedness that the market price of the security will fall..$^{85}$ Nonetheless, the Treasury seemingly wishes to straddle the fence of taxation when dealing with discounted preferred, imposing debt status on the shareholders and equity status on the corporate issuers. ${ }^{80}$ Section 385 could be used more creatively to solve a number of the problems outlined above.

\section{Remedies}

Many of the difficulties with the current regulatory scheme may be circumvented by careful tax planning. Competent tax counsel

equity ratio of the issuer must exceed $2: 1$; and the obligation must have been issued after October 9,1969 . This provision of the Code is so limited by its terms that it should, for the purposes of predicting the future scope of $\$ 385$, be regarded as the low water mark of what $\S 385$ could potentially provide. See BITTKER \& EUsTICE, supra note 33, at 4-15 to -29. See generally S. REP., supra note 2, at 138-39.

83. INT. REv. CODE of 1954, § 385(b). The predictions made in BITIKER \& Eustice, supra note 33 , at $4-18 \mathrm{n} .37$, as to "leading candidates for "super-factor" status" parallel the suggestions made in the Code by Congress for the most part.

84. But cf. the definition of preferred stock contained in Treas. Reg. $\$ 1.305-5(a)$ (1973).

85. P. Hunt, C. Williams \& G. Donaldson, Basic Business Finance 374-78 (3d ed. 1966).

86. Quite possibly Congress will precede the Treasury in correcting the bifurcated status of preferred stockholders and preferred stock issuers, at least with respect to preferred stock issued after some future date. In his recent economic proposal President Ford asked Congress

to enact tax legislation to provide that all dividends on preferred stock issued for cash be fully deductible by the issuing company. This should bring in more capital, especially for energy-producing utilities. It will also help other industries shift from debt to equity, providing a sounder capital structure.

N.Y. Times, Oct. 9, 1974, at 24, col. 1. While Ford proposes an effective partial elimination of the two-tiered system of taxation which taxes corporate income both when earned by the corporation and again when distributed to the shareholder, he demonstrates no concern for conceptual clarity. According to this proposal, preferred stock will continue to be characterized as equity-undoubtedly for the sake of capitalization objectives such as minimizing debt-equity ratios-while little significant tax law distinction remains. Note that "all dividends" should include constructive dividends on discounted preferred stock. 
may foresee and avoid problems created by sliding-scale or indeterminate term discounted preferred stock, or the thin distinction between bootstrap financing and a contingent interest. Other problems are not so easily handled. Short of a decision not to use discounted preferred at all, even the most sophisticated corporations cannot avoid the dissonance between imputed dividends and basis adjustments, or the problem in defining issue price when preferred is issued pursuant to a merger or acquisition. And it is far from inconceivable that those small, unsophisticated corporations which have a particular need to rely on seller-financed consolidations will be trapped by even the more transparent problems created by the current $\S 305$ regulations. Since confusion is inevitable under the current structure of taxation of preferred redemption premiums, some preventive action, even if it is only the writing of additional regulations or rulings, is clearly needed.

\section{A. The Courts}

Given the Treasury's broad authority under $\S 305$ to issue regulations governing the tax treatment of redemption premiums, courts will be loath to make substantial inroads on the current regulations. ${ }^{87}$ However, in the context of mergers and acquisitions the regulations potentially conflict with basic Code policy regarding tax-free transfers in acquisitions, ${ }^{88}$ and this conflict should give the courts some freedom to resolve the issue in favor of the taxpayer.

Since $\S 1.305-5$ of the regulations, pertaining to discounted preferred, does not deal explicitly with corporate combinations, and since $\S 1.305-1$ (c) does allow contingent payments of purchase price to occur substantially after stock has been exchanged for discounted preferred, the regulations themselves may be interpreted to exclude from ordinary income any redemption premiums which are in the nature of payments for the departing shareholders' capital investment. ${ }^{89}$ Alternatively, the courts could act more directly, declaring

87. The standard presumption of correctness could be well supported by INT. REv. CODE of 1954, $\$ 305$ (c), which gives the Treasury authority to prescribe regulations that identify changes in redemption as a $\$ 301$ distribution.

88. Cf. INT. REv. CoDe of 1954, $\$ 354(a)(1)$; note 75 supra. Broadly stated, absent $\S$ 306 tainting, receipt of preferred stock does not breach the continuity of interest principle, and is not boot.

89. Under a previous version of Treas. Reg. $\$ 1.305-3(b)(4)$ (1973), a conversion ratio increase on preferred stock would not be considered to be in discharge of a preferred stock dividend if "such distribution represents an adjustment of the consideration transferred in the exchange" and the adjustment was made within five years after the exchange. CCH 1972 Stand. Fed. TAX REP. \$ 2335A, 37 Fed. Reg. 4964 (1972). Current regulations have not preserved this principle. 
that $\$ 354(\mathrm{~b})(1)$ and the case law ${ }^{90}$ explicitly prohibit current income treatment of what is putatively a delay in purchase price.

\section{B. The Treasury and the Congress}

In contrast to the courts, the Treasury has a wide range of effective alternatives that it could pursue to resolve current problems with discounted preferred stock. Under the broad mandate of $\$ 305(\mathrm{c})$, the Treasury is free within wide limits to make whatever further provisions or revisions it decides would be appropriate. The Treasury's minimum effort should be to add substance to the current regulations. Under the present regulatory framework, unless one of the simplified examples is directly applicable, it is impossible to tell for certain what will happen to the cost basis of discounted preferred, how the issue price will be determined, in what magnitude distributions will be deemed to have been made when there is a partial redemption and how open-ended redemption plans shall be treated. The silence of the regulations on this and other similar matters should be broken by the Treasury.

The regulations under $\$ 305$ seem to assume that discounted preferred is issued during the normal course of business and is not issued pursuant to a merger or acquisition. When a preferred stock is sold on the open market at a discount, the amount of the discount may quite realistically be compared to a dividend payment on a preferred issue which pays cash yearly and is not discounted. However, in a corporate acquisition the discount may represent in whole or in part a deferred payment of purchase price.

Regardless of the means used to tax the constructive dividend element of the preferred's redemption premium, some effort should be made to segregate out that portion of the redemption premium which should be taxed at capital gains rates because it represents a payment of purchase price. Congress has provided the Treasury with a means of segregating interest charges from payments on capital. ${ }^{91}$ It would be reasonable for the Treasury to make use of this pro-

90. See Helvering v. Southwest Consol. Corp., 315 U.S. 194 (1942); Carlberg v. United States, 281 F. $2 d 507$ (8th Cir. 1960); James C. Hamrick, 43 T.C. 21 (1964). But see Gordon v. Commissioner, 424 F.2d 578 (2d Cir. 1970).

91. INT. REv. CODE OF $1954, \S 483$. This provision is used to impute the payment of interest where a capital asset is sold and payment of the purchase price is delayed. By imputing an interest charge, $\$ 483$ prevents the seller from taking interest as a capital gain rather than as ordinary income, while the buyer is prevented from increasing his cost basis by the amount of the interest. 
vision, $\S 483$ of the Code, to establish rules by which delayed purchase price could receive the proper capital gains treatment. ${ }^{92}$

The best course for the Treasury to take would be to decide openly the extent to which the $\S 1232$ discounted debt analogy should be applied. Section 385 is the potential vehicle for accomplishing this goal. Conceivably the yet unwritten regulations under $\$ 385$ could draw the line between debt and equity on either side of discounted preferred. As a better solution, perhaps only certain types of preferred should be characterized as debt-for example, discounted preferred with a definite date of redemption which is supported by a sinking fund, a specified redemption premium, with no option to convert to common, and with a high preference in the event of liquidation..$^{13}$ While this would seem to be an improbable provision under current predictions of the potential scope of $\S 385,{ }^{94}$ it is not unreasonable to reevaluate the future of $\$ 385$ in light of the apparently unexpected difficulties with $\S 305$ which it could resolve. Discounted preferred which is nonvoting, has no potential to participate in corporate growth via a conversion provision, and has the security of a specific redemption promise, does not bear the risks which are customarily associated with equity. If the Treasury intends to describe equity in terms of the risk characteristics of various financial instruments, it seems reasonable to treat highly secure discounted preferred as debt.

Should it be decided that some preferred securities are debt while others are equity, the Treasury should segregate redemption premium rules according to the two different types of preferred. Present rules which seem to draw an analogy to original issue discount debt taxation could be retained to regulate the types of preferred designated as debt. But for preferred stock which retains equity status, new regulations should be written.

Where preferred stock is to be treated as equity and an ordinary income result continues to seem desirable as a backstop to $\S 1232$,

92. In defining the term "securities" for the purposes of INT. REV. CoDE of 1954, $\$$ 354 , leading tax authorities observe that notes with terms of maturity of five years or less rarely qualify for tax-free status. See BITTKER \& Eustice, supra note 33, at 3-20. Perhaps the Treasury could articulate a similar test in determining whether equity-status advantages should accrue to discounted preferred stock. Thus preferred, with a brief period until redemption, may be considered to be indebtedness for all purposes of the Code, as governed by rules which are possible to promulgate under $\$ 385$.

93. The Court in John Kelley Co. v. Commissioner, 326 U.S. 521, 526 (1946), agreed with debt classification of a financial instrument which had priority over common but was subordinated to other creditors, had free assignability, and a definite maturity date. These are, of course, features included in many discounted preferred issues.

94. See note 81 supra. 
the tax treatment of preferred stock dividends under $\$ 306$ suggests a useful alternative to the present rules. ${ }^{95}$ As mentioned above, preferred stock issued as a dividend on common bears close resemblance to a cash dividend. Section 306 declares that such stock is tainted, and when it is disposed of, ordinary income results will usually follow. ${ }^{90}$ But this result attaches only upon disposition, in accordance with cash basis accounting principles. ${ }^{97} \mathrm{~A}$ taxing scheme similar to $\S 306$ would permit open-ended characterization which could be employed in situations where there are sliding-scale redemption premiums, premiums which are increased by cumulated but unpaid dividends, or where there is no definite corporate obligation to redeem the preferred.

Section 305 already follows this "tainting" procedure for preferred stock which has cumulated dividend arrearages that are discharged by increasing proportionate interest. ${ }^{98}$ Recognizing implicitly that business reasons, notably the risk involved, do not justify accrual, the Treasury taxes holders of such stock at ordinary income rates, but only upon disposition and the receipt of cash. ${ }^{99}$ Applying this same scheme for all redemption premiums would at least eliminate the need for cash basis taxpayers to accrue uncertain dividends on discounted preferred.

If the courts and the Treasury fail to resolve satisfactorily the currently bewildering tax treatment of discounted preferred, and if they do not succeed in restoring cash basis accounting in this field or defining the boundaries of debt and equity, then it would be incumbent upon Congress to examine carefully the problems which resulted from the minimum of guidance which $\$ 305$ (c) gave. Were the legislature

95. Discounted preferred provisions may be directed at the bail-out of earnings and profits, which parallels the policy basis of $\$ 306$, see note 17 supra.

96. There will be ordinary income only to the extent of corporate earnings and profits at the time of issuance of the preferred, INT. REv. CoDE OF 1954, $\$ 306$ (c)(2). In terms of a risk theory of differentiating debt and equity, it could be said that "section 306 stock" is not taxed as a receipt of cash until the holder alters his risk status through a redemption or sale.

97. Preferred stock issued during a reorganization generally does not present a direct problem of earnings and profits bail-out under INT. REV. CODE OF 1954, \$ 306 . Section 306 recognizes the important principle that during an acquisitive reorganization the ordinary income result of constructive preferred stock dividend rules is inapplicable because the new preferred stock is issued as an adjustment of equity interests rather than as a means of distributing corporate earnings, id. $\$ 306(\mathrm{~b})$. Consequently, the Code provides that only where preferred stock issued during reorganization has the same effect as a stock dividend will the stock be tainted as "section 306 stock," id. $\$ \S 306(\mathrm{c})(\mathrm{l})(\mathrm{B})$, (C). Therefore any question about capital gains versus ordinary income treatment of discounted preferred typically does not involve $\$ 306$ bail-out issues. It is merely a question of the applicability of general dividend characterization.

98. See notes 39.40 supra.

99. Treas. Reg. § 1.305-7(c) (1973). 
to act, it seems most appropriate that, in order to resolve the profound contradictions created under $\$ 305$, the revision be extensive.

Perhaps one source of the current difficulties is the graft of anticonglomerate policy onto the tax laws which pertain generally to corporate financing. If Congress wishes to restrict anticompetitive conglomerate practices, it would be more appropriate to strengthen the Antitrust Division of the Justice Department, the FTC, or the SEC. These departments of the government, and not the Treasury, have the expertise necessary to police the conglomerates. ${ }^{100}$

In all events, Congress should reevaluate the faulty premise that an increase in redemption price is necessarily the equivalent of payment of a cash dividend, even where the issuer of discounted preferred stock is under no obligation to redeem. The Code and the regulations require a revision which is sufficiently sophisticated to distinguish between instances where a preferred stockholder has no power to enforce realization of the retirement provision, and situations where, by virtue of corporate control, tacit pre-arrangement, or explicit contract, the holder may demand redemption..$^{101}$

\section{Conclusion}

Taxation of the redemption premium on discounted preferred stock has been treated entirely too casually by the Treasury. While a great deal of energy has been devoted to original issue discount indebtedness, as evidenced by the elaborate provisions of $\S 1232$ in both Code and regulations, redemption premiums on preferred were dealt with lightly. Congress left the details up to the Treasury, and the Treasury was content to make very scant provision, explained for the most part by example alone. It is apparent that the rules dealing with discounted preferred were written as a backstop to $\S 1232$, designed to prevent taxpayers from using preferred stock to gain back-door access to recently prohibited original issue discount investment results.

Where a particular kind of preferred stock is judged to be so analogous to original issue discount indebtedness that equity advantages should not be permitted, it follows that under the authority granted the Treasury by $\S 385$ the preferred should be characterized as debt

100. See Bittker, supra note 3 .

101. Congress may have occasion to consider the taxation of preferred stock dividends in the very near future. While attention will focus on the issuer's side of the equation, stockholder problems might be reviewed. See note 86 supra. 
for all purposes of the Code. However, where a preferred stock's degree of risk or participation in the growth and management of a corporation does not warrant debt treatment, the stock's equity character should be consistently respected. Deemed dividends on a preferred stock issue which is identified as equity should not be treated as a cash equivalent and taken immediately into income. The transaction should instead be treated as open-ended. Preferred stock bail-out rules under $\S 306$, and $\S 305$ provisions for cumulated dividend arrearages establish the principle that deemed dividends, when represented by increased holdings of equity, might well be taxed as ordinary income, but not until such equity is converted into cash. This principle applies equally to deemed dividends represented by redemption premiums.

Furthermore, where it can be demonstrated that all or part of a redemption premium represents a deferred payment of purchase price in a merger or acquisition, there is no justification for treating the premium (or the portion of it representing capital) as productive of current ordinary income. This treatment results in the anomaly of taxing a payment on purchase of a capital asset as a payment of a dividend, and it violates the principle that recognition of tax liability should be delayed in a merger or acquisition until equity assets are converted into cash or cash equivalents. 